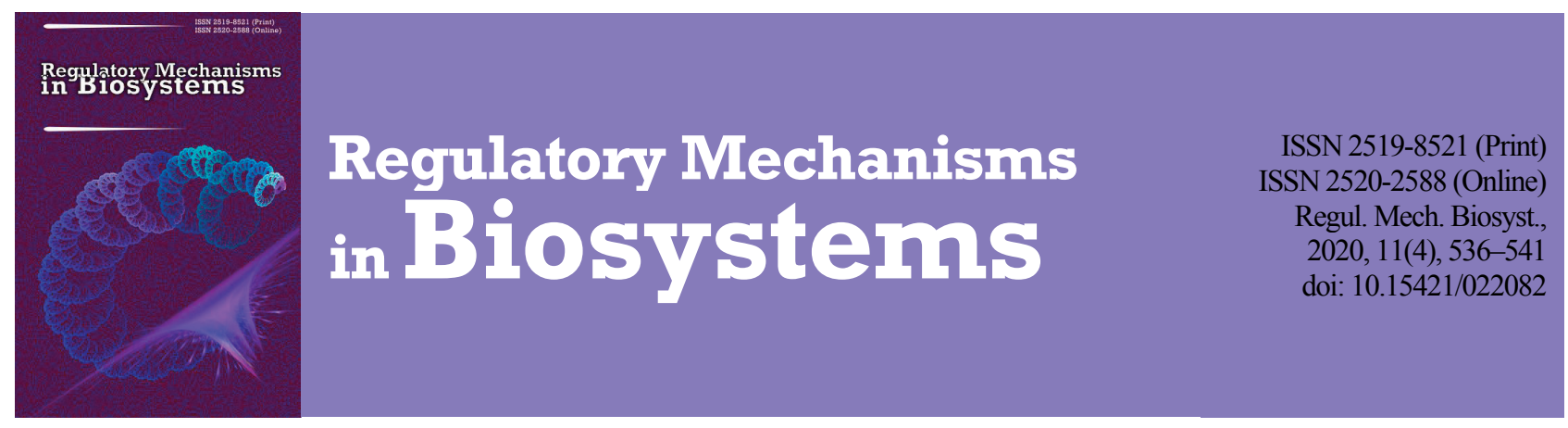

\title{
Effects of antihypertensive treatment on systemic inflammation, oxidative stress and proinflammatory cytokine levels
}

\author{
T. V. Ashcheulova, N. N. Gerasimchuk, O. N. Kovalyova, K. N. Kompaniiets, O. V. Honchar
}

Kharkiv National Medical University, Kharkiv, Ukraine

Article info

Received 20.10.2020

Received in revised form

16.11.2020

Accepted 18.11.2020

Kharkiv National Medical University, Nauky ave., 4, Kharkiv, 61022, Ukraine. Tel.: +38-096-120-68-72 E-mail: nino.gerasimchuk @gmail.com

\begin{abstract}
Ashcheulova, T. V., Gerasimchuk, N. N., Kovalyova, O. N., Kompaniiets, K. N., \& Honchar, O. V. (2020). Effects of antihypertensive treatment on systemic inflammation, oxidative stress and proinflammatory cytokine levels. Regulatory Mechanisms in Biosystems, 11(4), 536-541. doi:10.15421/022082

Hypertension in its origin is a heterogeneous and multisystemic disease. Evaluation of oxidative stress activity based on the level of 8-iso-PgF2 $\alpha$, proinflammatory activity based on tumour necrosis factor- $\alpha$, its type I soluble receptor, and C-reactive protein levels is relevant for further understanding of pathogenesis of hypertension and improvement of the early diagnostics of heart failure. 186 hypertensive patients were observed during a 2-months course of treatment, aged 30 to 65 years. Serum levels of 8 -iso-PgF2 $\alpha$ $(n=34)$, tumour necrosis factor- $\alpha$ and its type I soluble receptor were determined by ELISA before and after course of treatment. C-reactive protein level was determined by biochemical method. The control group included 16 clinically healthy individuals, aged 27 to 55 years. Hypertensive patients enrolled into the study were randomized into three groups that received different protocols of combined anti-hypertensive therapy: I clinical group - a combination of bisoprolol and indapamid, II - a combination of lacidipine and candesartan, III - a combination of fosinopril sodium and hydrochlorothiazide. On the background of combined antihypertensive therapy, we observed favourable dynamics of 8 -iso-PgF2 $\alpha$, tumour necrosis factor- $\alpha$ and its type I soluble receptor, and C-reactive protein levels. Taking into account the insignificance of the correlations revealed, a one-factor dispersion analysis was applied which allowed us to determine the influence of the grade and duration of hypertension on the dynamics of the studied parameters. It has been found that the grade of hypertension is related to an increase in TNF- $\alpha$ and 8-iso-PgF2 $\alpha$ serum levels, but not in TNF- $\alpha$ type I soluble receptor, and the duration of hypertension is related to an increase in C-reactive protein, TNF- $\alpha$ and its type I soluble receptor levels, with no relation to the level of 8 -iso-PgF2 $\alpha$. Thus, oxidative stress possibly promotes the activation of potentially damaging immune mechanisms mediated by proinflammatory cytokines, nonspecific inflammation and drives the further progression of lesions in the target organs.
\end{abstract}

Keywords: 8-iso-PgF2 $\alpha$; tumour necrosis factor- $\alpha$; type I soluble receptor; C-reactive protein; blood pressure.

\section{Introduction}

Hypertension occupies one of the leading places in the structure of cardiac pathology and presents a complex medical and social problem considering its high prevalence and the early development of complications. Hypertension in its origin is a heterogeneous and multisystemic disease. In the last decade, the role of immune inflammatory activation mediated by proinflammatory cytokines, systemic inflammation and oxidative stress (OS) in the pathogenesis of cardiovascular diseases, including hypertension, has been actively studied (Bautista et al., 2005; Mahmud \& Feel, 2005). The term "oxidative stress" (OS) is understood as a condition in which the amount of free radicals formed in the body is significantly higher than the activity of endogenous antioxidant systems that ensure their elimination (Kovalyova et al., 2005; Allison, 2016). It has been suggested that OS and immune inflammatory changes participate in the pathogenesis of cardiovascular dysfunction, are interrelated and can induce each other, forming a vicious circle (Kovalyova et al., 2015).

Among the proinflammatory cytokines, tumour necrosis factor- $\alpha$ (TNF- $\alpha$ ) deserves special attention in the context of hypertension. Firstly, this is due to the fact that, as shown by experiments and an insignificant number of clinical studies, hemodynamic stress caused by increased blood pressure (BP) is one of the stimuli to increase production and release of pro-inflammatory cytokines, including TNF- $\alpha$, into the bloodstream (Goldhaber et al., 1996; Grainger, 2007). Secondly, it is due to existing data on the ability of this cytokine to modulate the structure and function of the cardiovascular system through a number of mechanisms. As an example,
TNF- $\alpha$ is able to suppress myocardial contractility. This may be due to blocking of $\beta$-adrenergic signals, reduction of the content of nitric oxide in the heart, or changes in intracellular calcium homeostasis (Goldhaber et al., 1996). TNF- $\alpha$ can also induce structural changes in the myocardium of patients with hypertension and chronic heart failure, such as cardiomyocyte hypertrophy and interstitial fibrosis (Kovalyova \& Ashcheulova, 2003). In addition, TNF- $\alpha$ promotes apoptosis of cardiomyocytes, and also activates metalloproteinases and depresses the expression of their inhibitors, thus promoting cardiac remodeling ( $\mathrm{Li}$ et al., 2000; Haider et al., 2002) and eventually leading to cardiac dysfunction.

In healthy people, TNF- $\alpha$ is barely detectable in serum. Its level increases in infections under the influence of bacterial endotoxins (Vasan, 2006). There are two types of active receptors for TNF- $\alpha$ on the surface of almost all nuclear cell types that can virtually be cytokine targets. Soluble forms of receptors, which are considered endogenous inhibitors of TNF- $\alpha$, are formed by separating the extracellular fragments of active receptors (Simbirtsev, 2013). TNF- $\alpha$ type I receptor (sTNF- $\alpha$ RI) is the main mediator of cytokines' biological activity.

$\mathrm{C}$-reactive protein (CRP) is a recognized marker of the acute phase of inflammation. With the advent of new highly sensitive techniques for its quantitative determination, it attracts increasing attention of cardiologists. This is due to the data on elevated CRP levels having a possible predictive role for the development of the set of cardio- and cerebrovascular complications such as congestive heart failure, myocardial infarction, stroke, sudden cardiac death and peripheral vascular disease (Sproston \& Ashworth, 2018). The prognostic value of a high CRP level in patients with stable 
angina pectoris, acute coronary syndrome and myocardial infarction has been shown (Melnikov et al., 2019; Melnikov et al., 2020). However, it should be noted that there were fewer reports on the diagnostic value of this systemic inflammation marker in essential hypertension, and there is insufficient evidence of the relationship between CRP, TNF- $\alpha$ and 8-iso$\mathrm{PgF} 2 \alpha$ (8-isoprostane) as the main OS marker in patients with hypertension from the clinical studies.

According to current data, detection of 8-isoprostane in blood or urine is a sensitive method for evaluating the intensity of OS. 8-iso-PgF2 $\alpha$ is one of the most reliable and specific markers that allows us to assess the level of free radical production in the human organism in a wide spectrum of different diseases. 8-Isoprostane is a product of metabolism in reactions of arachidonic acid peroxidation that is isomeric to prostaglandin F2 $\alpha$. Its level is proportional to the amount of free radicals formed. This substance belongs to the family of eicosanoids that are a product of the nonenzymatic (free radical) oxidation of phospholipids of cellular biomembranes (Lawson et al., 1999; Cracowski et al., 2000). There is evidence (Greco et al., 2000; Czerska et al., 2016) of an increase in the level of 8 -isoprostane in neurodegenerative diseases, coronary heart disease and hypertension. A significant increase in the level of 8-isoprostane has been observed in a number of conditions characterized by increased oxidative activity, particularly in tobacco smoking (Morrow et al., 1995), diabetes mellitus (Davi et al., 1999), hypercholesterolemia (Davi et al., 1997). Evaluation of OS activity based on the levels of 8-isoprostane, TNF- $\alpha$ and its soluble type I receptor, and C-reactive protein levels might allow us to reveal the correlations between the level of OS, immune activation and nonspecific inflammation in the human organism, which is relevant for further understanding of pathogenesis of hypertension and improvement of the early diagnostics of heart failure.

The purpose of this research was to assess the activity of proinflammatory cytokines and C-reactive protein serum levels (as independent markers of systemic inflammation) in the context of oxidative stress development, depending on the severity and duration of hypertension, and their changes under the influence of combined antihypertensive therapy.

\section{Materials and methods}

The study was conducted in accordance with the current ethical requirements. The protocol of the study was approved by the Committee of Bioethics of Kharkiv National Medical University, Department of Propedeutics of Internal Medicine No. 2 and Nursing Care. Informed consent was obtained from all participants of the study. 202 subjects were examined in the in-hospital setting, including 186 patients with essential hypetension of grades 1 to 3 who had asymptomatic lesions in the target organs (left ventricular hypertrophy/generalized retinal angiopathy/carotid intimamedia thickening or presence of atherosclerotic plaques/microalbuminuria), aged 30 to 65 (mean $54.7 \pm 5.8$ ) years, who previously had not been receiving regular antihypertensive therapy. The control group included 16 clinically healthy individuals ( 8 male and 8 female), aged 27 to 55 (mean $43.7 \pm 4.2$ ) years, without cardiovascular, renal and endocrine anamnesis. Study participants included 149 female and 37 male patients, with the mean duration of disease of 10 years.

The Clinical Practice Guidelines for the Management of Arterial Hypertension of the European Society of Cardiology (ESC) / European Society of Hypertension (ESH) (2018) were used for verification of the diagnosis and assessment of the grade of hypertension. Exclusion criteria were: secondary hypertension, associated inflammatory and endocrine disorders (including diabetes mellitus) as well as other conditions that could have an impact on the activity of oxidative processes, including smoking anamnesis. Patients receiving statin therapy were not included into the study; statin-naïve patients who had indications for lipid-lowering therapy had been prescribed such after completion of the 2-month course of treatment. Of the patients enrolled into study, 33 had been diagnosed with essential hypertension of grade 1,58 - of grade 2, and 95 - of grade 3 . The level of 8-isoprostane as a main marker of OS was assessed in 34 patients, including 27 females and 7 males. Of this sub-group, 8 patients were diagnosed grade 1 hypertension, 8 - of grade 2 , and 18 - of grade 3 .

The contents of serum 8-isoprostane, TNF-alpha and its type I soluble receptor (sTNF- $\alpha \mathrm{RI}$ ) were determined in all subjects using the 8-isopro- stane ELISA ('US Biological”, USA), ProCon TNFa ("Protein contour”, Russian Federation) and sTNF- $\alpha$ RI EASIA ("BioSource Europe S.A.", Belgium) ELISA kits, respectively. The serum levels of C-reactive protein (CRP) were determined using the test-system for quantification of CRP ('Ukrmedservice Ltd.", Ukraine).

Hypertensive patients enrolled into study had been randomized into three groups that received different protocols of combined anti-hypertensive therapy. The aforementioned parameters were reassessed after two months of treatment. I clinical group $(n=102)$ received a combination of a $\beta$-adrenoblocker (BAB) and diuretic (D) (bisoprolol 2.5-10.0 mg/day, and indapamid $1.5-2.5 \mathrm{mg} /$ day). The daily dose of bisoprolol was administered by continuous slow titration, starting with low doses of $1.25 \mathrm{mg} /$ day. Gradually the dose was increased to the maximum tolerated or target dose under the control of clinical parameters, especially blood pressure and heart rate $(H R)$. II clinical group $(n=30)$ received a combination of a calcium channel blocker (CCB) and angiotensin receptor blocker (ARB) (lacidipine 2, $4 \mathrm{mg}$ and candesartan 4, 8 and $16 \mathrm{mg}$ ). III clinical group $(n=54)$ received a combination of an angiotensin-converting enzyme inhibitor (ACEi) and diuretic (D) (fosinopril sodium $20 \mathrm{mg} /$ day and hydrochlorothiazide $12.5 \mathrm{mg} /$ day). The levels of 8-isoprostane were assessed in 10,14, and 10 patients of the three clinical groups, respectively. The dose of medications was individually up-titrated in cases of need during the course of treatment. As one can see (Table 1) the different clinical groups were comparable in terms of age, gender structure and clinical course of hypertension.

\section{Table 1}

Comparative characteristic of clinical groups of patients with hypertension

\begin{tabular}{lccc}
\hline \multicolumn{1}{c}{ Parameters } & $\begin{array}{c}\text { I clinical } \\
\text { group } \\
(\mathrm{n}=102)\end{array}$ & $\begin{array}{c}\text { II clinical } \\
\text { group } \\
(\mathrm{n}=30)\end{array}$ & $\begin{array}{c}\text { III clinical } \\
\text { group } \\
(\mathrm{n}=54)\end{array}$ \\
\hline Sex & & & \\
Male, $\mathrm{n}$ & 20 & 6 & 11 \\
Female, $\mathrm{n}$ & 82 & 24 & 43 \\
Age, years & $54.5 \pm 5.4$ & $54.7 \pm 5.8$ & $54.5 \pm 5.4$ \\
Hypertension history, years & $9.6 \pm 0.7$ & $10.7 \pm 1.4$ & $9.7 \pm 1.4$ \\
Hypertension grade, \% & & & \\
1 & 17.6 & 23.3 & 14.8 \\
2 & 28.4 & 26.7 & 38.8 \\
3 & 54.0 & 50.0 & 46.4 \\
New York Heart Association class, \% & & & \\
0 & 11.9 & 16.7 & 16.6 \\
I & 19.6 & 20 & 22.2 \\
II & 65.6 & 60 & 59.3 \\
III & 2.9 & 3.3 & 1.9 \\
\hline
\end{tabular}

The results were statistically processed using Statistica 7.0 software packages (StatSoft Inc., USA). Mean values and their standard deviation $(\mathrm{x} \pm \mathrm{SD})$ are presented in the text and tables. The intergroup analysis was performed using one-way analysis of variance (ANOVA) with the calculation of Fisher test (F); Wilcoxon T-test was used for paired intragroup analysis, with differences considered significant at $\mathrm{P}<0.05$.

\section{Results}

Analysis of the activity of proinflammatory cytokines showed a significant increase in the levels of TNF- $\alpha$ in patients with hypertension compared to control: $187 \pm 18.1$ vs $13.2 \pm 3.4 \mathrm{pg} / \mathrm{mL}$, respectively $(\mathrm{P}<$ 0.001). A similar tendency was observed with respect to soluble fraction of TNF- $\alpha$ receptor. The value of sTNF- $\alpha$ RI in hypertension also exceeded that in the control group: $2.14 \pm 0.28 \mathrm{vs} 1.20 \pm 0.60 \mathrm{ng} / \mathrm{mL}$, respectively $(\mathrm{P}<0.001)$. An increase in the serum 8-isoprostane was also found in patients with hypertension compared to healthy controls: $17.2 \pm 3.1$ vs $1.41 \pm 0.25 \mathrm{pg} / \mathrm{mL}$, respectively $(\mathrm{P}<0.05)$. The level of 8-isoprostane in hypertensive patients was 12.2 times higher compared to the control group. Considering the available data on the importance of CRP as a marker of systemic inflammation in cardiovascular pathology and as a predictor of development of heart failure (HF) and hypertension, we assessed the levels of serum CRP in patients with hypertension and revealed values exceeding the control group $(6.23 \pm 0.33 \mathrm{mg} / \mathrm{L})$. In order to elucidate the influence of not only the presence, but also the grade of increase in blood 
pressure on the expression of TNF- $\alpha$, sTNF- $\alpha$ RI, CRP, and also to evaluate the presence and level of oxidative stress, all patients were divided into groups depending on the grade of hypertension (Table 2).

Unlike TNF- $\alpha$ and 8 -isoprostane, CRP levels did not significantly differ between groups. As one can see from Table 2, in patients with hypertension, a 3.2-fold, 7.1-fold and 18.4-fold increase (grades 1, 2, and 3, respectively) in the 8-isoprostane serum levels was observed compared to the control group. When comparing the levels of 8-iso-PgF2 $\alpha$ in patients with different grades hypertension, it was revealed that serum 8-isoprostane increased as the disease progressed: in patients with grade 3 hypertension, it exceeded by 5.8 times the value in patients with grade 1 and 2.6 times - in those with grade 2 .

The levels of TNF- $\alpha$, sTNF- $\alpha$ RI, 8-isoprostane, and CRP in the examined patients depended not only on the grade, but also on the duration of hypertension (Table 3 ).

Rank correlation analysis was performed to determine the relationship between blood pressure and levels of TNF- $\alpha$, CRP and 8 -isoprostane. The correlation coefficient $(\mathrm{r})$ between the grade of hypertension and serum TNF- $\alpha$ levels was $0.204(\mathrm{P}=0.25)$, for sTNF- $\alpha \mathrm{RI}-\mathrm{r}=-0.01(\mathrm{P}=$ 0.97), for 8-isoprostane $-r=0.11(P=0.94)$, for $C R P-r=0.02(P=$ $0.44)$. Correlation coefficients with the duration of hypertension were: for TNF- $\alpha-r=0.24(\mathrm{P}=0.17)$, for sTNF- $\alpha \mathrm{RI}-\mathrm{r}=0.17(\mathrm{P}=0.53)$, for 8-iso- prostane $-\mathrm{r}=0.01(\mathrm{P}=0.95)$, for $\mathrm{CRP}-\mathrm{r}=0.32(\mathrm{P}=0.74)$. Taking into account the insignificance of the correlations revealed, a one-factor dispersion analysis was applied to determine the influence of the grade and duration of hypertension on the dynamics of the studied parameters levels. It was found that the grade of hypertension was related to the serum levels of TNF- $\alpha$ and 8 -isoprostane $(\mathrm{F}=9.58, \mathrm{P}=0.002$ and $\mathrm{F}=8.34, \mathrm{P}=0.004$, respectively), but not sTNF- $\alpha \mathrm{RI}$ and $\mathrm{CRP}$, and the duration of hypertension was related to the levels of TNF- $\alpha$, sTNF- $\alpha \mathrm{RI}$ and $\mathrm{CRP}(\mathrm{F}=6.72$, $\mathrm{P}=0.003 ; \mathrm{F}=2.34, \mathrm{P}=0.006 ; \mathrm{F}=9.96, \mathrm{P}=0.002$, respectively), with no relation to the level of 8-isoprostane. Analysis of the relationships between the levels of 8-isoprostane, TNF- $\alpha$ and STNF- $\alpha$ RI has shown no significant correlations.

In the first group of patients on the background of treatment with bisoprolol and indapamide, the mean levels of TNF- $\alpha$ significantly decreased to $70.2 \mathrm{pg} / \mathrm{mL}$ compared to baseline before treatment, showing a $61.0 \%$ reduction (Table 4 ). The mean levels of soluble sTNF- $\alpha$ RI, which is a natural inhibitor of TNF- $\alpha$, increased to $0.24 \mathrm{ng} / \mathrm{mL}(11.1 \%)$ after treatment. A significant decrease in the TNF- $\alpha / \mathrm{sTNF}-\alpha \mathrm{RI}$ ratio by 34.4 $(64.9 \%)$ indicated a predominant increase in the level of sTNF- $\alpha \mathrm{RI}$ along with decrease in TNF- $\alpha$. Since soluble forms of receptors act as natural antagonists of TNF- $\alpha$, a decrease in this ratio reflects suppression of autoimmune and apoptotic activity in patients after treatment.

Table 2

Levels of TNF- $\alpha$, sTNF- $\alpha$ RI, CRP, and 8 -isoprostane depending on the grade of hypertension ( $x \pm \mathrm{SD})$

\begin{tabular}{lccc}
\hline \multicolumn{1}{c}{ Parameter } & \multirow{2}{*}{ Control group } & \multicolumn{2}{c}{ Patients with hypertension } \\
\cline { 2 - 3 } & & 1 grade & 2 grade \\
\hline TNF- $\alpha, \mathrm{pg} / \mathrm{mL}$ & $13.2 \pm 3.4$ & $112.0 \pm 26.1^{*}$ & $142.0 \pm 27.2^{* * *}$ \\
sTNF- $\alpha \mathrm{RI}, \mathrm{ng} / \mathrm{mL}$ & $1.20 \pm 0.60$ & $2.02 \pm 0.22^{*}$ & $2.13 \pm 0.16^{*}$ \\
8-isoprostane, $\mathrm{ng} / \mathrm{mL}$ & $1.41 \pm 0.25$ & $4.48 \pm 0.55^{* * *}$ & $117.0 \pm 18.5^{*}$ \\
CRP mg/L & $6.23 \pm 0.33$ & $6.25 \pm 0,57$ & $10.00 \pm 0.99^{* * * * *}$ \\
\hline
\end{tabular}

Note: ${ }^{*}-\mathrm{P}<0.05,{ }^{* *}-\mathrm{P}<0.01,{ }^{* * *}-\mathrm{P}<0.001$ vs control group; ${ }^{*}-\mathrm{P}<0.05,{ }^{*}-\mathrm{P}<0.01,{ }^{* *}-\mathrm{P}<0.001$ vs patients with grade 1 hypertension; ${ }^{\bullet}-\mathrm{P}<0.05,{ }^{\bullet \bullet}-\mathrm{P}<0.01$, - $-\mathrm{P}<0.001$ vs patients with grade 2 hypertension.

Table 3

Levels of TNF- $\alpha$, TNF- $\alpha$ RI, CRP, and 8-isoprostane in patients with different duration of hypertension, $y r s(x \pm S D)$

\begin{tabular}{|c|c|c|c|c|}
\hline \multirow{2}{*}{ Parameter } & \multirow{2}{*}{ Control group } & \multicolumn{3}{|c|}{ Patients with duration of hypertension, yrs } \\
\hline & & $<5$ & $5-10$ & $>10$ \\
\hline TNF- $\alpha, p g / m L$ & $13.2 \pm 3.4$ & $108.0 \pm 23.0^{*}$ & $128.0 \pm 25.8^{*}$ & $145.0 \pm 28.4^{* * \bullet \bullet}$ \\
\hline sTNF- $\alpha$ RI, ng/mL & $1.20 \pm 0.60$ & $2.08 \pm 0.21^{*}$ & $2.14 \pm 0.18^{*}$ & $2.20 \pm 0.19^{*}$ \\
\hline 8-isoprostane, $\mathrm{ng} / \mathrm{mL}$ & $1.41 \pm 0.25$ & $9.17 \pm 1.72^{* * *}$ & $19.30 \pm 4.09^{* * * * *+*}$ & $14.90 \pm 3.79^{* * *}$ \\
\hline CRP mg/L & $6.23 \pm 0.33$ & $6.08 \pm 0.65$ & $6.28 \pm 0.51$ & $6.38 \pm 0.59$ \\
\hline
\end{tabular}

Note: ${ }^{*}-\mathrm{P}<0.05,{ }^{* *}-\mathrm{P}<0.01,{ }^{* * *}-\mathrm{P}<0.001$, vs control group; ${ }^{\bullet}-\mathrm{P}<0.05,{ }^{\bullet}-\mathrm{P}<0.01,{ }^{\bullet \bullet}-\mathrm{P}<0.001$ vs patients with duration of hypertension $<5$ years; ${ }^{\bullet}-\mathrm{P}<0.05,{ }^{\bullet \bullet}-$ $\mathrm{P}<0.01, \cdots-\mathrm{P}<0.001$ vs patients with duration of hypertension $5-10$ years.

Table 4

Dynamics of the cytokines, CRP and 8-isoprostane in the course of combined antihypertensive therapy in the observed patients $(\mathrm{x} \pm \mathrm{SD})$

\begin{tabular}{|c|c|c|c|}
\hline Parameter & I group & II group & III group \\
\hline TNF- $\alpha, p g / m L$, prior to treatment & $115.0 \pm 19.6$ & $133.0 \pm 22.6$ & $78.2 \pm 23.7$ \\
\hline TNF- $\alpha, p g / m L$, after 2 months treatment & $44.8 \pm 8.21 * * *$ & $45.0 \pm 5.63^{* * *}$ & $40.6 \pm 15.8^{* * *}$ \\
\hline sTNF- $\alpha$ RI, ng/mL, prior to treatment & $2.17 \pm 0.12$ & $2.10 \pm 0.16$ & $2.25 \pm 0.21$ \\
\hline sTNF- $\alpha$ RI, ng/mL, after 2 months treatment & $2.41 \pm 0.03^{*}$ & $2.63 \pm 0.53 *$ & $2.38 \pm 0.19$ \\
\hline TNF- $\alpha /$ sTNF- $\alpha$ RI, prior to treatment & $53.0 \pm 17.4$ & $63.3 \pm 19.3$ & $34.8 \pm 12.2$ \\
\hline TNF- $\alpha /$ sTNF- $\alpha$ RI, after 2 months treatment & $18.6 \pm 7.8 * *$ & $17.1 \pm 6.4^{* *}$ & $17.1 \pm 6.6^{* *}$ \\
\hline 8 -isoprostane, $\mathrm{ng} / \mathrm{mL}$, prior to treatment & $20.5 \pm 17.4$ & $12.7 \pm 9.6$ & $20.2 \pm 11.9$ \\
\hline 8-isoprostane, $\mathrm{ng} / \mathrm{mL}$, after 2 months treatment & $12.3 \pm 7.27^{*}$ & $2.4 \pm 1.5^{*}$ & $10.2 \pm 7.61 *$ \\
\hline $\mathrm{CRP}$ mg/L, prior to treatment & $5.86 \pm 0.48$ & $6.81 \pm 0.59$ & $6.30 \pm 0.49$ \\
\hline $\mathrm{CRP}$ mg/L, after 2 months treatment & $3.85 \pm 0.36$ & $3.68 \pm 0.38 *$ & $5.14 \pm 0.42$ \\
\hline
\end{tabular}

Note: $*-\mathrm{P}<0.05, * *-\mathrm{P}<0.01, * * *-\mathrm{P}<0.001$ vs levels prior to treatment.

In the second group of patients, on the background of treatment with a combination of lacidipine and candesartan, the mean TNF- $\alpha$ levels decreased by $88 \mathrm{pg} / \mathrm{mL}(66.2 \%)$ compared to the baseline before treatment (Table 4). With respect to sTNF- $\alpha$ RI, the reverse trend was observed, that is, an increase in its mean level by $0.53 \mathrm{ng} / \mathrm{mL}(25.2 \%)$ after treatment. A $73.0 \%$ decrease in TNF- $\alpha / \mathrm{sTNF}-\alpha$ RI ratio reflected a significant decrease in the level of autoimmune activation under the influence of 10week $\mathrm{ARB}+\mathrm{CCB}$ therapy. In the third group of patients, the combination of fosinopril sodium with hydrochlorothiazide significantly reduced the mean TNF- $\alpha$ levels by $37.6 \mathrm{pg} / \mathrm{mL}$ (48.1\%). With respect to sTNF- $\alpha$ RI, an insignificant increase in its mean level after treatment by $0.13 \mathrm{ng} / \mathrm{mL}$
(5.8\%) was observed. The value of TNF- $\alpha /$ sTNF- $\alpha$ RI ratio decreased by 17.7 (by $50.9 \%$ ), compared to baseline before treatment, which also reflected a decrease in the level of autoimmune activation under the influence of therapy.

Analyzing the obtained data with respect to the level of 8-isoprostan $r$ two months from the start of therapy on the background of treatment, in the third group patients, its level decreased by $50 \%$ (2-fold) from the initial level. In the second clinical group, the reduction in serum levels of 8 isoprostane by $80.9 \%$ (5.2-fold) was observed after 2 months of treatment compared with the baseline. In the first group of patients, the levels of 8isoprostane also decreased by $40 \%$ (1.7-fold) from the initial level after 
two months of therapy. Thus, different protocols of combined therapy with beta-blocker plus diuretic (bisoprolol and indapamide) and ACE inhibitor plus diuretic (fosinopril and hydrochlorothiazide) expressed a similar effect on the dynamics of 8-isoprostane levels during two months of treatment. Analyzing the dynamics of CRP on the background of combined treatment, we obtained the following data: the mean values of serum CRP had decreased by $2.01 \mathrm{mg} / \mathrm{L}(34.3 \%)$, by $3.13 \mathrm{mg} / \mathrm{L}(46.0 \%)$ by $1.16 \mathrm{mg} / \mathrm{L}(18.4 \%)$ in the I, II and III clinical groups, respectively. Under the influence of combined antihypertensive therapy with all three schemes, there was an improvement in clinical status, expressed by a decrease in the intensity and frequency of headaches, dizziness, pain in the heart area, fatigue, and an increase in exercise tolerance as a result of significant reduction in blood pressure (Table 5). All patients who received treatment with one of the combined anti-hypertensive therapy regimens were discharged from the hospital (on the 10-14th day of treatment) in a satisfactory condition.

Table 5

Blood pressure and heart rate dynamics during the course of treatment $(x \pm S D)$

\begin{tabular}{lccc}
\hline \multicolumn{1}{c}{ Parameter } & I group & II group & III group \\
\hline Systolic blood pressure prior to treatment & $168.3 \pm 26.6$ & $176.0 \pm 27.2$ & $180.2 \pm 28.6$ \\
Systolic blood pressure after 2 weeks of treatment & $129.5 \pm 11.9^{* * *}$ & $131.6 \pm 11.0^{* * *}$ & $132.6 \pm 9.7^{* * *}$ \\
Diastolic blood pressure prior to treatment & $100.8 \pm 12.7$ & $105.2 \pm 14.1$ & $107.1 \pm 11.3$ \\
Diastolic blood pressure after 2 weeks of treatment & $75.5 \pm 6.3^{* * *}$ & $75.3 \pm 5.0^{* * *}$ & $76.5 \pm 5.8^{* * *}$ \\
Average BP blood pressure prior to treatment & $123.3 \pm 16.0$ & $128.8 \pm 17.6$ & $131.3 \pm 15.7$ \\
Average BP blood pressure after 2 weeks of treatment & $93.4 \pm 6.5^{* * *}$ & $93.9 \pm 6.2^{* * *}$ & $95.0 \pm 5.7^{* * *}$ \\
Pulse blood pressure prior to treatment & $67.5 \pm 19.9$ & $71.2 \pm 18.0$ & $73.1 \pm 22.2$ \\
Pulse blood pressure after 2 weeks of treatment & $54.0 \pm 11.8^{* * *}$ & $55.9 \pm 10.6^{* * *}$ & $55.6 \pm 10.1^{* * *}$ \\
HR prior to treatment & $83.4 \pm 11.9$ & $74.2 \pm 9.2$ & $78.4 \pm 12.1$ \\
HR after 2 weeks of treatment & $75.3 \pm 6.2^{*}$ & $76.7 \pm 4.8$ & $73.1 \pm 6.6^{*}$ \\
\hline
\end{tabular}

Note: ${ }^{*}-\mathrm{P}<0.05 ; * *-\mathrm{P}<0.01 ; * * *-\mathrm{P}<0.001$; vs levels prior to treatment.

In patients treated with bisoprolol and indapamide, a reduction in the mean values of office systolic blood pressure (SBP) by $38.8 \mathrm{~mm} \mathrm{Hg}$, office diastolic blood pressure (DBP) by $25.3 \mathrm{~mm} \mathrm{Hg}$, average BP by $29.8 \mathrm{~mm} \mathrm{Hg}$, pulse BP by $13.5 \mathrm{~mm} \mathrm{Hg}$ during the period of inpatient treatment was observed $(23.1 \%, 25.1 \%, 24.2 \%$, and $20.0 \%$, respectively vs levels prior to treatment, Table 5). In the group of patients who received candesartan and lacidipine, there were similar changes during the inpatient treatment in the mean values of the office SBP by $44.5 \mathrm{~mm} \mathrm{Hg}$, office DBP $29.9 \mathrm{~mm} \mathrm{Hg}$, mean BP by $34.8 \mathrm{~mm} \mathrm{Hg}$, pulse BP by $15.2 \mathrm{~mm} \mathrm{Hg}$ (25.3\%, 28.4\%, $27.1 \%$ and $21,4 \%$, respectively vs levels prior to treatment). In the third group (patients treated by fosinopril sodium and hydrochlorothiazide), during the period of inpatient treatment, there was a decrease in the average values of office SBP by $47.6 \mathrm{~mm} \mathrm{Hg}$, office DBP by $30.6 \mathrm{~mm} \mathrm{Hg}$, mean BP by $36.3 \mathrm{~mm} \mathrm{Hg}$, pulse BP by $17.5 \mathrm{~mm} \mathrm{Hg}$ $(26.4 \%, 28.6 \%, 27.6 \%$ and $24.0 \%$, respectively vs levels prior to treatment). Thus, there was a significant decrease in both office SBP and DBP and, accordingly, mean BP and pulse BP in enrolled patients, regardless of the group of drugs they received. The level of blood pressure reduction allowed us to reach the target values for both SBP and DBP.

A change was also found in the average heart rate during the inpatient treatment period: a decrease in the heart rate in patients taking bisoprolol plus indapamide and fosinopril plus hydrochlorothiazide by $8 \mathrm{bpm}(9.6 \%)$ and by $5 \mathrm{bpm}(6.7 \%)$, respectively. Conversely, in patients of group II HR tended to increase by $3 \mathrm{bpm}(3.4 \%)$ on average.

\section{Discussion}

The mean value of TNF- $\alpha$ was 14.2 times higher compared to control values, suggesting the possible role of hemodynamic stress as one of the stimuli for increasing synthesis and release of pro-inflammatory cytokines, in particular TNF- $\alpha$, into the circulation (Grander, 2004; Azra \& Feel, 2005; Bautista et al., 2005). The mean value of sTNF- $\alpha$ RI in patients with increased TNF- $\alpha$ activity (likely, due to increased blood pressure) was 1.78 times, or $78.3 \%$ higher, compared to normal subjects.

Numerous epidemiological studies have shown a relationship between tachycardia and hypertension. Increased heart rate is associated with many risk factors, including dyslipidemia, hyperinsulinemia, obesity, and elevated hematocrit. Tachycardia is a marker of increased activity of the sympathetic nervous system. It is known that a decrease in heart rate correlates with longer life in mammals. Moreover, B-blockers affect the reninangiotensin-aldosterone system (RAAS), inhibiting the release of renin by blockade of B1-receptors in juxtaglomerular apparatus of the kidneys. Bisoprolol is a $\beta$-blocker with a high degree of cardioselectivity (1:75); it does not effect the level of atherogenic fractions of lipids (triglycerides, cholesterol, low-density lipoproteins) in prolonged administration (Ostroumova \& Maksimov, 2012; Knjaz'kova, 2013). The combination of bisoprolol with indapamid is able to improve endothelial function due to the presence of antioxidant properties. An important role in this combination is played by indapamid, which, unlike other diuretics, has a direct vasodilator action (London, 2004).

Lacidipine occupies a special place among the CCBs, showing the most pronounced anti-atherosclerotic properties. Its antioxidant activity is comparable to that of vitamin $\mathrm{E}$ and exceeds that of all other CCB (Svishchenko, 2002). Lacidipine forms a stronger bond to the cellular membrane compared to other CCBs. This determines its high local concentration in the tissues of blood vessels (to which it is highly selective), which is particularly important in conditions of hypercholesterolemia, when the cellular membrane's availability to CCBs is decreased due to high cholesterol load. Lacidipine's binding to the cellular membrane remains strong even in the described conditions, being significantly higher than with other CCBs (Herbette, 1995). The tight bond with the membrane defines a longer duration of lacidipine action and its ability to intervene in the majority of intracellular processes at the early stages of atherogenesis. The main role in the action of the drug on various links of atherosclerotic process is given to its high vascular selectivity and the ability to tightly bind to the cellular membrane in conjunction with an intense antioxidant effect and the ability to optimize the calcium homeostasis. Importantly, the anti-atherogenic effect of lacidipine is not determined by its antihypertensive effect: it is observed even when using lacidipine in low doses that do not affect blood pressure (Svishchenko, 2002).

Fosinopril is the only angiotensin-converting enzyme inhibitor (ACEi) that retains the phosphinic acid residue in its chemical formula; it prevents conversion of angiotensin I to angiotensin II, resulting in reduction of vasopressor activity and aldosterone secretion (Preobrazhenskij \& Savchenko, 2000; Dzjak et al., 2005). Fosinopril is de-esterified in the liver or gastrointestinal mucosa and is converted to its active form, fosinoprilate (Ageev \& Mareev, 2000; Sirenko \& Rekovec, 2005). Fosinoprilate competitively binds to ACE, preventing ACE from binding to and converting angiotensin I to angiotensin II. Inhibiting the production of AII lowers peripheral vascular resistance, decreases afterload, and decreases blood pressure, thus helping to alleviate the negative effects of AII on cardiac performance. The second mechanism of action of ACEi on endothelial function is their ability to prevent degradation of bradykinin (Greene, 2000), as ACE is identical to the kinase II enzyme, which causes the conversion of bradykinin to its inactive form. Bradykinin is a potent stimulator of the release of endothelium-dependent relaxing factors such as nitric oxide, endothelium hyperpolarization factor and prostacyclin (PGI2).

The advantage of fosinopril is the balanced double way of excretionslightly more than half of the total amount of the drug $(54.0 \%)$ is excreted by the kidneys with urine, the rest $(46.0 \%)$ - by hepatic degradation of active metabolites with their sequential release through the gastrointestinal tract. It is important to note that the decrease in renal filtration increases 
proportionally the hepatic route of excretion of the drug, and on the contrary, in liver disease - increases the contribution of renal excretion. Actually, this pharmacokinetic feature of fosinopril is the basis of the important clinical recommendations: no additional correction of fosinopril doses is usually required in renal and hepatic failure (Ageev \& Mareev, 2000; Karpov, 2001). This characteristic feature of fosinopril makes it a safer choice than other ACEi for heart failure patients with impaired kidney function resulting from impaired renal perfusion as fosinopril can still be eliminated by the liver, preventing excessive increase of its serum levels.

The results of current study allow us to suggest that in individuals with grade 1 hypertension, increase of sTNF- $\alpha$ RI $(2.02 \pm 0.22 \mathrm{ng} / \mathrm{mL})$ at high levels of the circulating TNF- $\alpha(112 \pm 26 \mathrm{ng} / \mathrm{mL})$ can possibly be regarded as an adaptive mechanism that, on one hand, reduces the number of active receptors on the surface of target cells, and on the other hand, may neutralize the bioactivity of TNF- $\alpha$ through the soluble receptor forms (sTNF- $\alpha \mathrm{RI}$ ) binding with the latter. In patients with grade 2 hypertension, a parallel increase in STNF- $\alpha \mathrm{RI}(2.13 \pm 0.16 \mathrm{ng} / \mathrm{mL})$ was probably not enough to neutralize the negative effect of TNF- $\alpha(142 \pm 27 \mathrm{ng} / \mathrm{mL})$, as could be evidenced by a further increase in the TNF- $\alpha / \mathrm{sTNF}-\alpha \mathrm{RI}$ ratio (66.7 vs 55.4 in grade 1 hypertension and 11.0 in normotensive individuals). At the maximal levels of blood pressure the levels of TNF- $\alpha$ were decreasing $(117 \pm 19 \mathrm{ng} / \mathrm{mL})$, which possibly could be due to its binding to sTNF- $\alpha$ RI. On the other hand, we can suggest the possibility of TNF- $\alpha$ triggering a cascade leading to apoptosis of cells producing cytokine. The further increase in sTNF- $\alpha$ RI on the background of a decrease in TNF- $\alpha$ has a positive significance. The fact that the TNF- $\alpha / \mathrm{sTNF}-\alpha \mathrm{RI}$ value was 53.4, with the TNF- $\alpha$ levels also still exceeding those in grade 1 hypertension and healthy individuals, could indicate that such a level of sTNF- $\alpha$ RI was unable to inactivate TNF- $\alpha$ cytotoxicity.

According to the single-factor dispersion analysis, there was an increase in the CRP serum levels in patients with hypertension. This increase depended only on the duration of hypertension, but not on the grade of BP elevation; there was also no significant correlation between CRP and BP, possibly being consistent with existing data on the definition of CRP as an independent risk factor for hypertension. In particular, an increased level of CRP had been shown in normotensive individuals who later developed essential hypertension. The increased level of CRP is related to the deterioration of endothelium-dependent relaxation, posing a potential risk of developing hypertension. In the hypertensive population, it is established that CRP is an independent predictor of atherosclerosis progression, more significant than pulse and systolic blood pressure. Our findings suggest that elevated CRP levels can be considered as a marker of systemic inflammation in hypertensive patients (Bautista, 2001; Onat et al., 2008).

Taking into account the correlations revealed, it can indicate the role of OS in the pathogenesis of hypertension as a damaging mechanism that promotes the activation of immune mechanisms, nonspecific inflammation and the further progression of the disease. OS causes damage to the vascular endothelium, and the main disorders in the vascular wall that are characteristic for hypertension are endothelial dysfunction and hypertrophy of the smooth muscle cells.

\section{Conclusions}

The obtained data allows us to suggest the possible role of oxidative stress as one of the important pathogenetic mechanisms in hypertension, manifested in this study by an increase in serum 8-isoprostane levels compared to clinically healthy individuals. Thus, oxidative stress possibly promotes the activation of potentially damaging immune mechanisms mediated by pro-inflammatory cytokines, nonspecific inflammation and drives the further progression of lesions in the target organs.

An increase in circulating TNF- $\alpha$, sTNF- $\alpha$ RI, CRP and 8-isoprostane levels supports data on involvement of immune activation and oxidative stress in pathogenesis of hypertension. It was found that the grade of hypertension influences the increase in the serum levels of TNF- $\alpha$ and 8-isoPgF $2 \alpha$, but not of sTNF- $\alpha$ RI, and the duration of hypertension affects the activity of the CRP, TNF- $\alpha$ and sTNF- $\alpha$ RI, with no effect on the levels of 8-iso-PgF2 $\alpha$.
The data obtained in the course of two months treatment testifies to the anti-inflammatory and anti-apoptotic effects of the combined antihypertensive therapy. The most pronounced result was observed in individuals receiving combined therapy with lacidipine plus candesartan and bisoprolol plus indapamide.

It is important that further studies are made to assess the activity of proinflammatory cytokines, namely tumour necrosis factor- $\alpha$ and its type I soluble receptor, levels of C-reactive protein as an independent marker of systemic inflammation, levels of 8-isoprostane as a marker of oxidative stress, involving larger study populations with long follow-up periods. The results of advanced research will help in the formation of pathogenetically justified and prognostically significant antihypertensive therapy regimens.

\section{References}

Ageev, F. T., \& Mareev, V. U. (2000). Fozinopril v lechenii serdechno-sosudistyh zabolevanij [Fozinopril in the treatment of cardiovascular diseases]. Russkij Medicinskij Zhurnal, 2, 56-61 (in Russian).

Allison, S. J. (2016). Oxidative stress and immune activation in hypertension. Nature Reviews Nephrology, 12(1), $4-8$.

Azra, M., \& Feely, J. (2005). Arterial stiffness is related to systemic inflammation in essential hypertension. Hypertension, 46, 1118-1122.

Bautista, L. E., Lopez-Jaramillo, P., Vera, L. M., Casas, J. P., Otero, A. P., \& Guaracao, A. I. (2001). Is C-reactive protein an independent risk factor for essential hypertension? Journal of Hypertension, 19(5), 857-861.

Bautista, L. E., Vera, L. M., Arenas, I. A., \& Gamarra, G. (2005). Independent association between inflammatory markers (C-reactive protein, interleukin-6, and TNF-a) and essential hypertension. Journal of Human Hypertension, 19, 149-154.

Cracowski, J. L., Stance-Labesque, F., \& Bessard, G. (2000). Isoprostanes: New markers of oxidative stress. Fundamental and clinical data. La Revue de Médecine Interne, 21(3), 304-307.

Czerska, M., Zieliński, M., \& Gromadzińska, J. (2016). Isoprostanes - A novel major group of oxidative stress markers. International Journal of Occupational Medicine and Environmental Health, 29(2), 179-190.

Davi, G., Alessandrini, P., Mezzetti, A., Minotti, G., Bucciarelli, T., Costantini, F., Cipollone, F., Bittolo. B., Ciabattoni, G., \& Patrono, C. (1997). In vivo formation of 8-epi-PGF2 is increased in hypercholesterolemia. Arteriosclerosis, Thrombosis, and Vascular Biology, 17, 3230-3235.

Davi, G., Ciabattoni, G., Consoli, A., Mezzetti, A., Falco, A., Santarone, S., Pennese, E., Vitacolonna, E., Bucciarelli, T., Costantini, G. F., Capani, F., \& Patrono, C. (1999). In vivo formation of 8-iso-prostaglandin F2 and platelet activation in diabetes mellitus: Effects of improved metabolic control and vitamin E supplementation. Circulation, 99(2), 224-229.

Dzjak, G. V., \& Kolesnik, T. V. (2005). Jeffektivnost' fozinoprila v lechenii arterial'noj gipertenzii [Effectiveness of fosinopril in the treatment of arterial hypertension]. Ukrainskij Kardiologicheskij Zhurnal, 2, 30-35 (in Russian).

Goldhaber, L., Kim, K. H., Natterson, P. D., Lawrence, T., Yang, P., \& Weiss, J. N. (1996). Effects of TNF-alpha on $\left[\mathrm{Ca}^{2+}\right]$ I and contractility in isolated adult rabbit ventricular myocytes. American Journal of Physiology-Heart and Circulatory Physiology, 271, 1449-1455.

Grainger, D. J. (2007). TGF- $\beta$ and atherosclerosis in man. Cardiovascular Research, $74(2), 213-222$

Grander, D. N., Vowinkel, T., \& Petnehazy, T. (2004). Modulation of the inflammatory response in cardiovascular disease. Hypertension, 43(5), 924-931.

Greco, A., Mingetti, L., \& Levi, G. (2000). Isoprostanes, novel markers of oxidative injury, help understanding the pathogenesis of neurodegenerative diseases. Neurochemical Research, 25(9-10), 1357-1364.

Greene, E. L., Verlarde, V., \& Jaffa, A. A. (2000). Role of reactive oxygen species in bradykinin-induced mitoden-activated proteinkinase and C-FOS induction in vascular. Hypertension, 35(4), 942-947.

Haider, N., Narula, N., \& Narula, J. (2002). Apoptosis in heart failure represents programmed cell survival, not death, of cardiomyocytes and likelihood of reverse remodeling. Journal Cardiac Failure, 8(6), 512-517.

Herbette, L. G. (1995). The interaction of lacidipine with biological membranes: The molecular of calcium antagonists. Reviews in Contemporary Pharmacotherapy, $6(1), 8-12$.

Karpov, U. A. (2001). Fozinopril pri lechenii arterial'noj gipertenzii (FLAG): Rossijskaja programma ocenki prakticheskoj dostizhimosti celevyh urovnej arterial'nogo davlenija [Fozinopril in the treatment of hypertension (FLAG): Russian program for assessing the practical achievement of target blood pressure levels] Russkij Medicinskij Zhurnal, 9(10), 14-17 (in Russian).

Kovaljova, O. N., \& Ashcheulova, T. V. (2002). Faktor nekroza opuholej- $\alpha$. Klinicheskoe issledovanie aktivnosti pri arterial'noj gipertenzii [Tumor necrosis factor- $\alpha$. Clinical trial of activity at arterial hypertension]. Imunologija ta Alergologija, 4, 64-66 (in Russian). 
Kovaljova, O. N., Ashcheulova, T. V., Herasymchuk, N. N., \& Safargalina-Kornilova, N. A. (2015). Rol' oksidativnogo stressa v stanovlenii i progressirovanii gipertonicheskoj bolezni [Role of oxidative stress in the formation and progression of hypertensive disease]. Nauchnye Vedomosti Belgorodskogo Gosudarstvennogo Universiteta Medicina Farmacija, 201, 5-10 (in Russian).

Kovaljova, O. N., Belovol, A. N., \& Zaika, M. V. (2005). Rol' oksidativnogo stressa $\mathrm{v}$ kardiovaskuljarnoj patologii [The role of oxidative stress in cardiovascular disease.] Zhurnal Akademii Medicinskih Nauk Ukrainy, 11(4), 660-670 (in Russian).

Lawson, J. A., Rokach, J., \& FitzGerald, G. A. (1999). Isoprostanes: Formation, analysis and use as indices of lipid peroxidation in vivo. Journal of Biological Chemistry, 274 (35), 24441-24444.

Li, Y. Y., Feng, Y. Q., Kadokami, T., Mc Tiernan, C. F., Draviam, R., Watkins, S. C., \& Feldman, A. M. (2000). Myocardial extracellular matrix remodeling in transgenic mice overexpressing tumor necrosis factor $\alpha$ can be modulated by anti-tumor necrosis factor $\alpha$ therapy. Proceedings of the National Academy of Sciences, 97(23), 12746-12751.

Mahmud, A., \& Feel, J. (2005). Arterial stiffness is related to systemic inflammation in essential hypertension. Hypertension, 46(5), 1118-1122.

Mel'nikov, I. S., Kozlov, S. G., Chumachenko, P. V., Saburova, O. S., Guseva, O. A., Prokof'eva, L. V., \& Gabbasov, Z. A. (2019). Monomernyj C-reaktivnyj belok i lokal'naja vospalitel'naja reakcija v stenke koronarnyh arterij u bol'nyh stabil'noj ishemicheskoj bolezn'ju serdca [Monomeric C-reactive protein and local inflammatory reaction in the wall of the coronary arteries in patients with stable coronary artery disease]. Russian Journal of Cardiology, 24(5), 56-61 (in Russian)

Mel'nikov, I. S., Kozlov, S. G., Saburova, O. S., Avtaeva, J. N., Prokof'eva, L.V., \& Gabbasov, Z. A. (2020). Sovremennoe polozhenie o roli monomernogo S-reaktivnogo belka $\mathrm{v}$ patologii sosudov $\mathrm{i}$ aterotromboze [Current position on the role of monomeric C-reactive protein in vascular pathology and atherothrombosis]. Current Pharmaceutical Design, 26, 37-43 (in Russian).

Morrow, J. D., Frei, B., Longmire, A. W., Gaziano, M. J., Lynch, S. M., Shyr, Y., Strauss, W. E., Oates, J. A., \& Roberts, L. J. (1995). Increase in circulating products of lipid peroxidation ( $\mathrm{F}_{2}$-isoprostanes) in smokers. Smoking as cause of oxidative damage. New England Journal of Medicine, 332, 1198-1203.

Onat, A., Can, G., \& Hergenç, G. (2008). Serum C-reactive protein is an independent risk factor predicting cardiometabolic risk. Metabolism, 57(2), 207-214.

Preobrazhenskij, D. V., Savchenko, M. V., Kiktev, V. G., \& Sidorenko, B. A. (2000). Fozinopril-pervyj predstavitel' novogo pokolenija ingibitorov angiotenzinprevrashhajushhego fermenta [Fosinopril is the first representative of a new generation of angiotensin-converting enzyme inhibitors]. Kardiologija, 5, 75-82 (in Russian).

Simbirtsev, A. S. (2013). Czitokiny v patogeneze infekczionnykh i neinfekczionnykh zabolevanij cheloveka [Cytokines in the pathogenesis of infectious and noninfectious human diseases]. Meditsinskii Akademicheskii Zhurnal, 13(3), 18-41 (in Russian).

Sirenko, J. N., \& Rekovec, O. L. (2005). Rol' fozinoprila v lechenii arterial'noj gipertenzii [Role of fosinopril in treatment arterial hypertension]. Ukrainskij Kardiologicheskij Zhurnal, 2, 5-15 (in Russian).

Sproston, N. R., \& Ashworth, J. J. (2018). Role of C-reactive protein at sites of inflammation and infection. Frontiers in Immunology, 9, 754.

Svishchenko, Y. P. (2002). Antyatyrohenna diia lytsydypinu: Doslidzhennia ELSA (European Lacidipine Study on Atherosclerosis) [Anti-atherogenic effect of lacidipine: Study ELSA (European Lacidipine Study on Atherosclerosis)]. Medytsyna Svitu, 7, 24-29 (in Ukrainian).

Vasan, R. S. (2006). Biomarkers of cardiovascular disease: Molecular basis and practical considerations. Circulation, 113(19), 2335-2362. 